\title{
Interview with a Clinical Equipment Training Co- ordinator and Union Representative
}

John Mullen

\section{(2) OpenEdition}

\section{Journals}

Electronic version

URL: http://journals.openedition.org/rfcb/4144

DOI: $10.4000 /$ rfcb.4144

ISSN: 2429-4373

\section{Publisher}

CRECIB - Centre de recherche et d'études en civilisation britannique

\section{Electronic reference}

John Mullen, «Interview with a Clinical Equipment Training Co-ordinator and Union Representative », Revue Française de Civilisation Britannique [Online], XXIV-3 | 2019, Online since 29 August 2019, connection on 04 September 2019. URL : http://journals.openedition.org/rfcb/4144 ; DOI : 10.4000/ rfcb. 4144

This text was automatically generated on 4 September 2019.

\section{(i) $(9)$}

Revue française de civilisation britannique est mis à disposition selon les termes de la licence Creative Commons Attribution - Pas d'Utilisation Commerciale - Pas de Modification 4.0 International. 


\section{Interview with a Clinical Equipment Training Co-ordinator and Union Representative}

John Mullen

\section{$\mathrm{JM}$ : When did you start working for the NHS and what are the different jobs you have done inside it ?}

1 Gwyneth Powell-Davies : I started in January 1986 as a technician checking and repairing electronic equipment such as infusion pumps, patient monitors and so on. This has been a growing area as more technology has come into the health sector. The department name and the structure and even location of our larger employer has changed over the years but I still work for the same section which I would now describe as the 'medical equipment management organisation' within an 'acute' NHS Trust. We not only mend equipment but ensure the Trust has an accurate inventory, an equipment library, user training and can confirm action is taken on any nationally distributed 'Medical Device Alerts'.

2 In 2002, I moved sideways from my job as a 'senior' repair technician to become the 'Clinical Equipment Training Co-ordinator' organising and delivering a documented and recorded training scheme for clinically trained equipment users. Later I then moved 'upwards' in the structure of my department after my union supported me in achieving recognition of the greater responsibility of this role so that I am now employed on a higher grade. 


\section{$\mathrm{JM}$ : When did you first become a union rep, and what particular union roles have you played?}

G P-D : I joined the same union as other departmental colleagues soon after starting my work. This was the union (then ASTMS) that organised the Pathology Labs in many hospitals including our own and I found that there was only ONE rep in the whole hospital who worked in the labs. When he sent round a note about needing more reps, I volunteered. This was within a year of my starting. With the existing rep's support I visited all the departments with ASTMS members getting to know speech therapists, psychologists, pharmacy workers, the Medical Artist, Medical photographers, EEG and ECG technicians and, although I had no one contesting my rep position, we made sure there was agreement to my taking the role and I was voted in.

NHS is a multi-union environment and there will be a Joint Union Committee in any large NHS organisation. Over the next few years I played a part in encouraging new workplace reps to come forward for our own union and I went along to represent our union at the JUC, briefly holding the role of JUC chair at one point.

After my second child was born in 1995 I managed to find a new person to take on the rep role for my own technical department but I always aimed to attend my union branch which covered NHS members in our union throughout a large geographical area around Bristol (up to Gloucester, down to Weston-Super-Mare and across to Salisbury). I held the relatively lowly branch officer role of 'vice-chair' in late 2008 but found myself stepping in to support the branch secretary as he became ill and then was readily elected for this more time-consuming role when he stood down. Since then I have always been a branch officer through some turbulent and interesting times for our large branch, due to NHS and union re-organisations and wider political debates. We have never, however, been a workplace branch that gets directly involved with negotiating with management. In large NHS organisations it is normally the JUC (not any individual union) that negotiates with management.

6 Since 2010, I have been an elected rep at work again and I could attend the JUC but I have left UNITE representation there to other UNITE reps, especially our senior rep who gets some dedicated days 'facility time' each week.

7 I am currently 'Co-Chair' of UNITE Bristol Area Health Sector branch (after deciding not to stand in the, this time contested, election for branch secretary). (I am 'co-chair' because the same meeting split evenly in voting for chair however many times they retook the vote!)

8 Over the last eight years I have attended some national conferences (UNITE health sector, UNITE Rules and UNITE Policy conferences). I have attended various committees in the intricate UNITE structures including Area Activist and Regional committee and I have been an occasional UNITE delegate at the Bristol Trades Council (local all-industry union meeting of lay union activists from TUC affiliated unions). I currently attend the quarterly UNITE 'RISC' for my sector - South West Regional Industrial Sector Committee for Health. 


\section{JM : Could you briefly describe your present workplace, and your previous one if you have changed?}

G P-D : As briefly explained above I have not myself changed employer but the local subsection of the NHS that is my employer has changed over my head. In 1986 I was taken on by Frenchay Health Authority. Based then in a Porta-kabin shared with the nascent IT department and situated between asbestos-roofed wards (originally thrown up in WW2) that characterised Frenchay Hospital, our department serviced equipment equally in the state of the art Neurosurgery department across the corridor and in all the other NHS organisations in a geographical area to the north and east of Bristol such as the TVs in long-stay wards for people with learning difficulties.

I sometimes joke that I shall probably finish my NHS career in a Porta-kabin as has been the fate of other non-clinical departments in what I characterise as the 'health factories' of today, built too small on the assumption that we can forever speed up the throughput of our human material. However for the moment I have the fortune to work on Level 6 of the PFI-built Brunel Building at Southmead Hospital and I can survey the slightly larger area where the 'acute' physical health needs of the population are served by North Bristol NHS Trust. For departments like mine so little has changed in a way. Our main work is for the operating theatres and wards in our stream-lined employer but 'service-level agreements' are signed for maintenance work for community organisations (though we tend to concentrate on medical devices these days).

\section{$\mathrm{JM}$ : What is union density like ? How has it fluctuated in the years you have worked there, if it has?}

11 G P-D : Without checking statistics this will be an impression. I imagine my own department is a microcosm of the overall situation. For all unions in the NHS I should think union density has been sustained over the years with occasional boosts but a constant drain away as people retire. When I joined the NHS I found there were older members of staff who took it for granted that they should be in a union but it took effort by active union reps to pull in newer people or those who had resisted so far. This would also characterise the situation now.

\section{$\mathrm{JM}$ : When you first began, what were the main issues in working conditions in particular, that unionists were concerned about? What happened on these issues in the following years?}

12 G P-D : The NHS is a rock battered by the seas of neo-liberalism: cuts, privatisation, attrition of nationally determined terms and conditions.

13 In 1990, I petitioned with Junior doctors who kick-started an active local campaign against Mrs Thatcher's government's plans for the NHS. A slogan on a poster was 'The 
Government is finalising its plans to dismantle the NHS'. It is just that the NHS (and its public support) has proved to be formed of harder strata than anyone realised.

\section{JM : Was there a before and after $1997 ?$}

G P-D : The main thing most NHS staff would have noticed after the election of the Labour government would have been the move from the use of individual Trust logos for our headed notepaper back to the standard NHS banner.

Looking back at the trajectory (to more cuts, more privatisation, more locally determined pay and conditions) there is no doubt that election of Labour was one of the brakes. Other brakes would be public and union campaigns to defend our NHS and the very real limits to the profits that can be made that occasionally become apparent.

However after their election defeat in 1997 Tory spending limits on the NHS were adhered to for the first two years. After that increased spending came with a 'concordat' with the private sector to remove limits on involvement in the provision of public health (see for example 'NHS plc' by Alyson Pollock.) One could characterise the situation as cuts OR privatisation under Labour but cuts AND privatisation under the Tories.

17 I finish writing this the week of the confident 2018 Labour Party conference which will leave many health campaigners and trade unionists enthused with hope that next time round a Labour government will be finally committed to reversing the trend of the last 30 years.

\section{$\mathrm{JM}$ : What have been the main effects on you and your fellow workers of the various reorganisations of the NHS ?}

18 G P-D : Each NHS re-organisation is announced as an improvement for patients but usually mainly entails an attempt to cut costs in some way. The gradual trajectory has been as I describe. For anyone who has managed to stay an NHS employee over the years I can discern less certainty about the future job and pension security than in previous years. For any union branch colleagues who find themselves outside the NHS there can be a very abrupt change to pay, pensions and job security.

\section{JM : Recent decades have seen important changes in the way women, gay people and transgender people are seen in society. Has there been a development on the way management or union deal with issues pertaining to these groups?}

G P-D : In these areas there is absolutely no doubt that there have been improvements. Thirty years ago when AIDS was a new threat and of great concern to health workers, I heard the chair of a union committee (in the context that the disease was associated mainly with gay sex) talk about people bringing it on themselves. Such talk would be unacceptable now. 
The whole ethos pushed by management and unions now is one of respect for all and celebration of diversity. Within unions there are equality roles and committees. Within my workplace, the chief executive (a woman) has an annual breakfast on International Woman's day publicised and celebrated and to which any female employee can apply to go. I have just used a few clicks from the staff Intranet site to find there are guidelines 'to support staff who wish to transition'.

\section{$\mathrm{JM}$ : What are the present challenges on working conditions and pay?}

G P-D : There has just been agreement on an NHS pay deal that was in the opinion of some 'oversold' to us by our own unions. GMB was the ONLY major NHS union to recommend rejection of the deal when union members were balloted. The deal was negotiated after a campaign by all 14 unions (including the non-TUC RCN, UNISON, UNITE, GMB and the smaller unions for dedicated groups of staff such as dieticians or radiographers). It did breach the government's 'pay cap' of $1 \%$ but it ties us to a three year transition to a completely new pay structure that will involve an element of individual performance pay.

There is a possibility that anger will spill out over the paucity of the initial pay rise once it is coupled with the effect of the dates of annual increments and the already existing increases in pension contributions. However unless we have a national rebellion that changes the battlefield, the real challenge to trade unionists will be to get our colleagues to join the unions and strengthen the hand of the JUCs in local negotiations on the local interpretations of movement through the pay grades.

What is interesting is that the spark for some more confident local struggles has been sometimes the threats or effects of privatisation for smaller groups of our colleagues. The new scam is the 'wholly-owned subsidiary' where services are not even contracted out of the NHS but where an NHS organisation creates its own private company. At my Trust a strong campaign including a joint union petition knocked back one such plan. In other parts of the country plans have gone through but outrage has broken out when even the 'oversold' national pay deal is not applied to these newly privatised staff.

\section{AUTHOR}

\section{JOHN MULLEN}

Professeur, Université de Rouen Normandie 